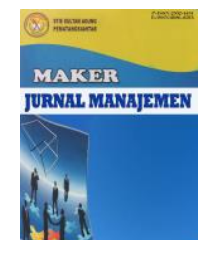

Maker: Jurnal Manajemen

Program Studi Manajemen STIE SULTAN AGUNG

Volume 6- Nomor 1, Juni 2020, (Hlm 87-95)

Available online at: http://www.maker.ac.id/index.php/maker

\title{
DAMPAK PENERAPAN AKUNTANSI PERTANGGUNGJAWABAN TERHADAP KINERJA MANAJERIAL PADA PERUSAHAAN DAERAH AIR MINUM (PDAM) TIRTAULI PEMATANGSIANTAR
}

\author{
Ruth Tridianty Sianipar ${ }^{1}{ }^{*}$, Robert Tua Siregar ${ }^{2)}$, Hery Pandapotan Silitonga ${ }^{3)}$, Karin Putri \\ Azura Pulungan ${ }^{4)}$ \\ 1,2,3,4 Program Studi Manajemen, STIE Sultan Agung. Jalan Surabaya No. 19, Kota Pematangsiantar, \\ Sumatera Utara, 21118, Indonesia. \\ *E-mail: ${ }^{1}$ ruthsianipar@stiesultanagung.ac.id, ${ }^{2}$ tuasir@gmail.com, ${ }^{3}$ herysilitonga@ gmail.com, \\ ${ }^{4}$ karinputriazura2109@yahoo.co.id
}

\begin{abstract}
Abstrak
Penelitian ini bertujuan untuk untuk mengetahui Pengaruh Akuntansi Pertanggungjawaban Terhadap Kinerja Manajerial Pada Perusahaan Daerah Air Minum (PDAM) Tirtauli Pematangsiantar. Metode penelitian yang digunakan metode deskriptif kuantitatif, populasi pada penelitian ini adalah seluruh Karyawan Perusahaan Daerah Air Minum (PDAM) Tirtauli Pematangsiantar, lalu sampel yang digunakan pada penelitian ini menggunakan sampel nonprobability. Sampel pada penelitian ini adalah 56 (lima puluh enam) orang pada bagian manajerial. Teknik pengumpulan data menggunakan kuisioner, teknik analisis data yang digunakan uji asumsi klasik, uji regresi linear sederhana, uji hipotesis, koefesien korelasi, dan koefesien determinasi. Berdasarkan hasil penelitian ditarik kesimpulan bahwa Akuntansi pertanggungjawaban berpengaruh positif terhadap kinerja manajerial Pada Perusahaan Daerah Air Minum (PDAM) Tirtauli Pematangsiantar, semakin baik penerapan akuntansi pertanggungjawaban akan semakin meningkatkan kinerja manajerial.
\end{abstract}

Kata kunci: Akuntansi Pertanggungjawaban, Kinerja Manajerial

\begin{abstract}
This study aims to determine the effect of Responsibility Accounting on Managerial Performance in Perusahaan Daerah Air Minum (PDAM) Tirtauli Pematangsiantar. The research method used quantitative descriptive method, the population in this study were all employes at Perusahaan Daerah Air Minum (PDAM) Tirtauli Pematangsiantar, samples in this study used nonprobability samples. The sample in this study was 56 (fifty-six) Managerial people, data collection techniques using questionnaires, data analysis techniques used were classical assumption tests, simple linear regression tests, hypothesis tests, correlation coefficients, and coefficients of determination. Based on the results of the study concluded that responsibility accounting has a positive effect on managerial performance in Perusahaan Daerah Air Minum (PDAM) Tirtauli Pematangsiantar, the better the application of responsibility accounting will further enhance managerial performance.
\end{abstract}

Keywords: Responsiblility Accounting, Manajerial Performance

Article History: Received 27 June 2020 Accepted 27 June $2020 \quad$ Published 27 June 2020 


\section{PENDAHULUAN}

Setiap perusahaan akan berusaha untuk meningkatkan efektifitas dan efesiensi kinerja perusahaanya. Dengan semakin berkembang dunia usaha pada saat ini penggunaan teknologi yang canggih, ilmu pengetahuan, serta strategi-strategi yang digunakan untuk mendukung semua kegiatan perusahaan agar tujuan dari perusahaan dapat tercapai.

Penyelenggaraan pemerintahan berkewajiban dalam memberikan pelayanan publik yang baik dan bertanggungjawab (Silalahi, M. et al. 2020). Proses penetapan dan pencapaian tujuan membutuhkan kemampuan manajemen dalam mengelola perusahaan. Dalam perkembangannya perusahaan semakin komplek, menyebabkan pemimpin perusahaan tidak dapat memantau secara langsung seluruh kegiatan operasional perusahaan. Untuk menyikapi hal tersebut. Pemimpin perusahaan harus mengadakan pendelegasian wewenang serta tanggungjawab kepada seorang manajer (kepala sub bagian). Dalam mengelola keuangan pemerintah daerah membutuhkan reaksi yang cepat kinerja aparat pemerintah daerah (Sembiring et al., 2020).

Dalam peraturan pemerintah No. 57 didirikan Badan Usaha Milik Daerah (BUMD), dengan pendirian Badan Usaha Milik Daerah (BUMD) diharapkan kesejahteraan masyarakat tercapai. Salah satu dari BUMD tersebut adalah Perusahaan Daerah Air Minum (PDAM) yang merupakan salah satu unit usaha milik daerah yang bergerak dalam distribusi air bersih bagi masyarakat umum. Tugas pokok yang dimiliki ialah menyelenggarakan pengelolaan air minum untuk meningkatkan kesejahteraan masyarakat yang mencakup aspek sosial, kesehatan, pelayanan umum dan memupuk pendapatan.
Unit usaha milik daerah Kota Pematangsiantar yang bergerak dalam distribusi air minum bagi masyarakat umum adalah Perusahaan Daerah Air Minum (PDAM) Tirtauli Kota Pematangsiantar. PDAM Tirtauli Kota Pematangsiantar berkewajiban memenuhi kebutuhan air bersih. Untuk mencapai tujuan dari PDAM Tirtauli Kota Pematangsiantar dalam memberikan pelayanan yang baik bagi masyarakat dalam penyediaan air minum, sekaligus mampu memberikan sumbangan bagi pemerintah berupa pendapatan. Dibutuhkan kinerja manajerial yang baik dalam menjalankan fungsi-fungsinya. Kinerja manajerial merupakan hal yang sangat penting dalam manajemen dalam keseluruhannya dikarenakan dengan kinerja manajerial dapat menjadi ukuran keberhasilan suatu perusahaan (Rahmawati, Budiwibowo, \& Murwani, 2017).

Kinerja manajerial digunakan dalam melakukan tindakan yang berhubungan dengan peningkatan kerja, membantu para pengambilan keputusan untuk menentukan siapa saja yang berhak menerima reward ataupun sebaliknya, menentukan promosi atau transfer, mengevaluasi kebutuhan pelatihan dan pengembangan bagi pegawai, memandu untuk menentukan jenis karir yang dapat dicapai, mempengaruhi perekrutan pegawai, serta membantu menjelaskan kesalahan apa saja yang terjadi dalam manajemen (Silitonga \& Astuty, 2018).

Kinerja manajerial tersebut dapat dilihat dari kecakapan manajer dalam melaksanakan kegiatan yang telah direncanakan. Salah satu yang digunakan manajerial dalam peningkatan kinerja manajerialnya dengan melakukan perencanaan, pengkoordinasian dan untuk mengevaluasi pengawasan adalah anggaran. Perencanaan di Perusahaan Daerah Air 
Minum (PDAM) Tirtauli Pematangsiantar ternyata belum terselesaikan ditahun sebelumnya, dan evaluasi manajerial yang belum optimal, hal ini dibuktikan dengan belum terealisasinya anggaran laba yang diprogramkan oleh Perusahaan Daerah Air Minum (PDAM) Tirtauli Pematangsiantar. Pada tahun 2017 anggaran laba yang terrealisasi sebesar 55,62\%, dan pada tahun 2018 anggaran laba yang terrealisasi sebesar 55,96\%. Hal ini menunjukkan bahwa kinerja Perusahaan Daerah Air Minum (PDAM) Tirtauli Pematangsiantar tidak mencapai yang dianggarakan dan mengalami penurunan.

Kinerja manajerial membutuhkan pengendalian, terdapat dua unsur pengendalian yaitu struktur pengendalian yang terdiri dari pusat-pusat tanggungjawab serta proses pengendalian manajemen. Pengendalian dilakukan dengan cara menerapkan akuntansi pertanggungjawaban. Dengan adanya akuntansi pertanggungjawaban perusahaan dapat merekam seluruh aktivitas usaha serta dapat mengetahui unit yang bertanggungjawab terhadap aktivitas dan menentukan unit yang bertanggungjawab terhadap aktivitas dan dapat menentukan unit usaha yang tidak berjalan efesien, dan memberikan informasi tentang pengumpulan, pelaporan biaya dan pendapatan dilakukan sesuai dengan pusat pertanggungjawaban dalam organisasi dengan tujuan agar dapat ditunjuk orang (kelompok) yang bertanggungjawab terhadap penyimpangan dari biaya dan penghasilan yang dianggarkan (Sari, 2013).

Pada Perusahaan Daerah Air Minum (PDAM) Tirtauli Pematangsiantar akuntansi pertanggungjawaban belum optimal berjalan hal ini dibuktikan dengan kurangnya bukti pelaporan untuk kegiatan yang dilakukan serta belum terdapatnya pemisahaan biaya yang terkendali dengan yang tidak terkendali. Karena tidak adanya pemisahan biaya tersebut membuat jumlah biaya PDAM meningkat. Meningkatnya biaya dari yang dianggarkan, seperti pada tahun 2017 biaya yang direalisasikan sebesar 416,68\%, dan pada Tahun 2018 sebsar 263,74\%. (Berdasarkan Data Laporan Laba Rugi Perusahaan Daerah Air Minum (PDAM) Tirtauli Pematangsiantar, Rencana Kerja Anggaran Perusahaan Tahun 2017 dan 2018 Perusahaan Daerah Air Minum (PDAM) Tirtauli Pematangsiantar).

Adapun permasalahan yang diangkat dalam penulisan ini adalah bagaimana Pengaruh Penerapan Akuntansi Pertanggungjawaban Terhadap Kinerja Manajerial Pada Perusahaan Daerah Air Minum (PDAM) Tirtauli Pematangsiantar. Adapun tujuan dari penulisan ini adalah untuk mengetahui Pengaruh Penerapan Akuntansi Pertanggungjawaban Terhadap Kinerja Manajerial Pada Perusahaan Daerah Air Minum (PDAM) Tirtauli Pematangsiantar.

\section{LANDASAN TEORI}

Kinerja manajerial merupakan kemampuan manajer dalam melaksanakan kegiatan manajerial diantaranya perencanaan, investigasi, koordinasi evaluasi, supervisi, pengaturan, staf (staffing), negosiasi dan representasi (Mahoney, Dkk 1963). Kinerja manajerial adalah prestasi kerja yang telah dicapai oleh individu atau sekelompok orang dalam melaksanakan tugas dan tanggungjawab mereka. Kinerja ini biasanya ditentukan atas dasar fungsi-fungsi manajemen klasik meliputi prestasi manajerial dalam planning, investigating, coordinating, evaluate, supervising, staffing, negotiating, representating, dan kinerja secara menyeluruh yang dikembangkan oleh Mahoney dkk (1963). 
Akuntansi pertanggungjawaban dapat digunakan untuk mengukur berbagai pencapaian setiap pusat pertanggungjawaban dengan menggunakan data (informasi) yang dibutuhkan oleh para manajer dalam mengoperasikan pusat pertanggungjawaban (Hansen, 2013). Akuntabel merupakan proses mengevaluasi kegiatan yang dapat dipertanggungjawaban (Suleman at al., 2020)

Akuntansi pertanggungjawaban mengarah pada proses akuntansi yang melaporkan apakah manajer pusat pertanggungjawaban dapat mengatur pekerjaan yang menjadi tanggungjawabnya atau yang berada di bawahnya, dan mengevaluasi hasil kerja pusat pertanggungjawaban untuk meningkatkan operasi-operasi perusahaan diwaktu yang akan datang. Dalam menilai pusat pertanggungjawaban, dapat dilihat dari beberapa aspek struktur organisasi, anggaran serta sistem biaya dan sistem pelaporan (Mulyadi, 2008).

Akuntansi pertangggungjawaban memberikan informasi yang dapat digunakan dalam mengendalikan aktivitas organisasi, informasi tersebut menekankan hubungan antara informasi dengan menajer yang bertanggungjawaban terhadap perencanaan dan realisasinya. Berdasarkan infromasi yang diperoleh dibutuhkan sebuah pengendalian, pengendalian tersebut dapat dilakukan dengan cara memberikan peran bagi setiap manajer untuk merencanakan pendapatan atau biaya yang menjadi tanggungjawabnya.

Informasi mengenai kinerja yang dibuat manajer dalam menggunakan berbagai sumber daya untuk melaksanakan peran manajer tersebut dalam mencapai sasaran perusahaan dapat. Dengan penerapan akuntansi pertanggungjawaban dengan baik, maka akan diperoleh informasi akuntansi masa lalu yang berperan sebagai pengukur kinerja di masa yang akan datang.

Fungsi akuntansi pertanggungjawaban sebagai alat analisis tentang pencapaian di masa lalu, dan menjadi bahan masukkan untuk masa akan datang. Penelitian serupa juga dilakukan (Cahyani \& Damayanthi, 2019), (Lubis \& Suzan, 2016), (Lukito, 2015), (Kinasih \& Aisyah, 2013), dan (Tin \& Hidayat, 2012), yang berkesimpulan bahwa dengan penerapan akuntansi pertanggungjawaban akan meningkatkan kinerja manajerial.

\section{METODE}

Penelitian ini adalah penelitian asosiatif dengan menggunakan metode deskriptif kuantitatif yang menekankan pada pengujian teori melalui pengukuran variabel berupa angka-angka yang selanjutnya dilakukan analisis dengan menggunakan prosedur statistik.Penelitian ini dilakukan pada Perusahaan Daerah Air Minum (PDAM) Tirtauli di Kota Pematangsiantar yang beralamat di Jl. Porsea No.2 Kota Pematangsiantar, Sumatera Utara. Populasi pada penelitian ini adalah seluruh Karyawan Perusahaan Daerah Air Minum (PDAM) Tirtauli Pematangsiantar yang berjumlah 360 (Tiga Ratus Enam Puluh) orang. Sampel yang digunakan pada penelitian ini menggunakan sampel nonprobability. Sampel pada penelitian ini adalah 56 (lima puluh enam) orang Manajerial di Perusahaan Daerah Air Minum (PDAM) Tirtauli Pematangsiantar. Data yang digunakan dalam penelitian ini adalah data primer. Teknik analisis data yang digunakan uji asumsi klasik, uji regresi linear sederhana, uji hipotesis, koefesien korelasi dan koefesien determinasi. 


\section{HASIL DAN PEMBAHASAN}

Perusahaan Daerah Air Minum (PDAM) Tirtauli Pematangsiantar merupakan salah satu perusahaan penyedia air minum yang sangat penting bagi masyarakat Kota Pematangsiantar.

\section{Statistik Deskriptif}

Statistik deskriptif juga digunakan untuk mengetahui deskripsi suatu data Hasil statistik deskriptif dari masing-masing variabel dapat pada Tabel 1 di bawah ini:

Tabel 1. Statistik Deskriptif

\begin{tabular}{|l|r|r|}
\hline \multirow{2}{*}{} & \multicolumn{1}{|c|}{$\mathrm{N}$} & \multicolumn{1}{c|}{ Std. Deviation } \\
\cline { 2 - 3 } & Statistic & \multicolumn{2}{|c|}{ Statistic } \\
\hline $\mathrm{X}$ & 56 & $\mathbf{8 , 7 2 7 9 2}$ \\
$\mathrm{Y}$ & 56 & $\mathbf{6 , 2 4 8 4 3}$ \\
Valid N & 56 & \\
(listwise) & & \\
\hline
\end{tabular}

Sumber : data diolah (2020)

Dari Tabel 1 di atas nilai standar deviasi yang bervariasi, akuntansi Pertanggungjawaban (X) nilai standar deviasi akuntansi pertanggungjawaban adalah 8,72792 yang berarti penyimpangan atas akuntansi pertanggungjawaban sangat kecil, dan kinerja manajerial (Y) nilai standar deviasi adalah 6,24843 yang berarti penyimpangan kinerja manajerial sangat kecil, dengan demikian dapat ditarik kesimpulan indikator kinerja manajerial menjadi perhatian tinggi para manajerial pada Perusahaan Daerah Air Minum (PDAM) Tirtauli Pematangsiantar.

\section{Uji Asumsi Klasik \\ Uji Normalitas}

Uji normalitas bertujuan untuk menguji apakah dalam model regrasi, variabel penggangu atau residual memiliki distribusi normal. Bila uji asumsi ini dilanggar maka uji statistik menjadi tidak valid. uji normalitas dalam penelitian ini menggunakan kolmogorov-Smirnov test. Berikut hasil uji normalitas dengan menggunakan kolmogorov-Smirnov test:
Tabel 2. Uji Normalitas

\begin{tabular}{|c|c|c|}
\hline & & $\begin{array}{c}\text { Unstandardized } \\
\text { Residual }\end{array}$ \\
\hline \multicolumn{2}{|l|}{$\mathrm{N}$} & 56 \\
\hline \multirow{3}{*}{$\begin{array}{l}\text { Normal } \\
\text { Parameters }\end{array}$} & Mean & ,0000000 \\
\hline & $\begin{array}{l}\text { Std. } \\
\text { Deviation }\end{array}$ & 4,93046702 \\
\hline & Absolute & , 143 \\
\hline \multirow{2}{*}{$\begin{array}{l}\text { Most Extreme } \\
\text { Differences }\end{array}$} & Positive & ,105 \\
\hline & Negative &,- 143 \\
\hline \multicolumn{2}{|c|}{ Kolmogorov-Smirnov Z } & 1,068 \\
\hline \multicolumn{2}{|c|}{ Asymp. Sig. (2-tailed) } & 204 \\
\hline
\end{tabular}

Dari Tabel 2 di atas dapat terlihat Sig. (2-tailed) total keseluruhan variabel keseluruhan 0,204>0,05, artinya data dinyatakan berdistribusi normal. Dapat dikatakan memenuhi persyaratan untuk analisis regresi.

\section{Uji Multikolinearitas}

Uji multikoliniearitas bertujuan untuk menguji apakah dalam model regresi yang terbentuk ada korelasi yang tinggi atau sempurna di antara variabel bebas atau tidak. Uji multikoliniearitas yang digunakan dalam penlitian ini adalah uji multikoliniearitas dengan TOL (Tolerance) dan Variance Inflation Factor (VIF). Hasil uji multikoliniearitas sebagai berikut:

Tabel 3. Uji Multikolinearitas

\begin{tabular}{|c|c|c|}
\hline \multirow[t]{2}{*}{ Model } & \multicolumn{2}{|c|}{ Collinearity Statistics } \\
\hline & Tolerance & VIF \\
\hline 1 (Constant) & & \\
\hline$X$ & 1,000 & 1,000 \\
\hline
\end{tabular}

Sumber : data diolah (2020)

Berdasarkan Tabel di atas Variance Inflation Factor (VIF) variabel akuntansi pertanggungjawaban (X) sebesar 1,000. Dengan demikian Variance Inflation Factor (VIF) lebih kecil dari 10, maka pada model regresi yang terbentuk tidak terjadi gejala multikolinier. 


\section{Uji Heteroskedastisitas}

Untuk menguji apakah dalam model regresi terjadi ketidaksamaan varian residual dari satu pengamatan ke pengamatan yang lain digunakan uji heterokedastisitas. Uji heteroskedastisitas yang digunakan dalam penelitian ini adalah dengan metode analisis grafik. Hasil pengujian heteroskedastisitas dengan metode analisis grafik sebagai berikut:

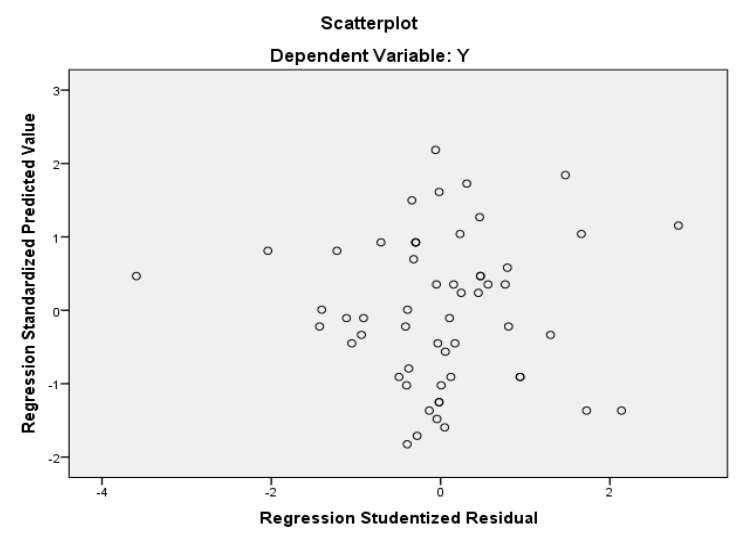

Gambar 1

Gambar Scatterplot

Sumber : data diolah (2020)

Berdasarkan Gambar 1 di atas, tampak bahwa titik-titik menyebar secara acak di atas maupun di bawah angka nol dan tidak menunjukkan pola tertentu. Dari hasil tersebut dapat ditarik kesimpulan bahwa model regresi tidak mengandung gejala heteroskedastisitas.

\section{Uji Regresi Linear Sederhana}

Regresi linear sederhana digunakan peneliti dengan maksud untuk mengetahui ada atau tidaknya pengaruh akuntansi pertanggungjawaban terhadap kinerja manajerial.Analisis regresi linier sederhana pada penelitian ini dengan hasil sebagai berikut:
Tabel 4. Regresi Linear Sederhana

\begin{tabular}{|c|c|c|c|c|}
\hline \multirow[t]{2}{*}{ Model } & \multicolumn{2}{|c|}{$\begin{array}{l}\text { Unstandardized } \\
\text { Coefficients }\end{array}$} & \multirow[t]{2}{*}{$t$} & \multirow[t]{2}{*}{ Sig. } \\
\hline & $B$ & $\begin{array}{l}\text { Std. } \\
\text { Error }\end{array}$ & & \\
\hline \multirow{2}{*}{$\begin{array}{ll}1 & \text { (Constant) } \\
\mathrm{X}\end{array}$} & 20,097 & 4,731 & 4,248 & ,000 \\
\hline & 440 & 077 & 5,721 & ,000 \\
\hline
\end{tabular}

a. Dependent Variable: $Y$

Sumber : Data Diolah (2020)

Berdasarkan tabel 4, model persamaan regresi linear berganda yang diperoleh adalah:

\section{Kinerja Manajerial = 20,097 + 0,440 Akuntansi Pertanggungjawaban}

Dari persamaan regresi di atas dapat diketahui bahwa akuntansi pertanggungjawaban berpengaruh positif terhadap kinerja manajerial pada pada Perusahaan Daerah Air Minum (PDAM) Tirtauli Pematangsiantar.

\section{Uji Hipotesis (Uji t)}

Uji statistik t dilakukan untuk menguji apakah variabel bebas (akuntansi pertanggungjawaban) secara individual mempunyai hubungan yang signifikan atau tidak terhadap variabel terikat (kinerja manajerial). Untuk kriteria Uji t dilakukan pada tingkat $\alpha=0.05$ dengan nilai $\mathrm{t}$ untuk $\mathrm{n}$ $=56-2=54$ adalah 2,005. Untuk itu $t_{\text {hitung }}$ $=5,335$ dan $\mathrm{t}_{\text {tabel }}=2,005$.

Berdasarkan Tabel 4 di atas, nilai $t_{\text {hitung }}$ akuntansi pertanggungjawaban sebesar 5,721 dan $t_{\text {tabel }}$ dengan $\alpha=5 \%$ diketahui sebesar 2,005. Dengan demikian $t_{\text {tabel }}$ lebih kecil sama dengan $t_{\text {hitung }}$ dan $t_{\text {hitung }}$ lebih besar dari $t_{\text {tabel }}$ dan nilai signifikansi sebesar 0,000 (lebih kecil dari 0,05) artinya $\mathrm{H}_{0}$ diterima, hal ini menunjukkan akuntansi pertanggungjawaban berpengaruh terhadap kinerja manajerial pada Perusahaan Daerah Air Minum (PDAM) Tirtauli Pematangsiantar. 


\section{Koefesien Korelasi}

Koefisien korelasi (r) menunjukkan seberapa besar korelasi atau hubungan antara variabel-variabel independen dengan variabel dependen. Berikut hasil pengolahannya:

Tabel 5. Koefisien Korelasi

\begin{tabular}{|l|c|r|r|r|}
\hline Model & $\mathrm{R}$ & $\begin{array}{c}\mathrm{R} \\
\text { Square }\end{array}$ & $\begin{array}{c}\text { Adjusted R } \\
\text { Square }\end{array}$ & $\begin{array}{c}\text { Std. Error of } \\
\text { the Estimate }\end{array}$ \\
\hline 1 &, $\mathbf{6 1 4}^{\mathrm{a}}$ &, 377 & $\mathbf{3 6 6}$ & 4,97591 \\
\hline
\end{tabular}

a. Predictors: (Constant), $X$

b. Dependent Variable: $Y$

Sumber : Data Diolah (2020)

Berdasarkan tabel 5 di atas, dapat dilihat bahwa nilai koefisien korelasi (r) adalah sebesar 0,614, yang artinya terdapat hubungan yang kuat antara akuntansi pertanggungjawaban dengan kinerja manajerial pada Perusahaan Daerah Air Minum (PDAM) Tirtauli Pematangsiantar.

\section{Koefesien Determinasi}

Koefisien determinasi menunjukkan kemampuan variabel independen menjelaskan variasi perubahan pada variabel dependennya. Berdasarkan tabel 5 di atas nilai koefisien determinasi (Adjusted $\mathrm{R}$ Square) menunjukkan angka 0,366 atau $36,6 \%$ yang berarti bahwa tinggi rendahnya kinerja manajerial dapat dijelaskan oleh akuntansi pertanggungjawaban. Sedangkan sisanya $63,4 \%$ dijelaskan oleh faktor lainnya yang tidak dijelaskan dalam penelitian ini.

\section{Pengaruh}

Akuntansi

Pertanggungjawaban Terhadap Kinerja Manajerial

Hasil penelitian mengenai pengaruh akuntansi pertanggungjawaban terhadap kinerja manajerial. Dari persamaan regresi di atas dapat diketahui bahwa akuntansi pertanggungjawaban berpengaruh positif terhadap kinerja manajerial dengan model persamaan regresi Kinerja Manajerial $=$ $20,097+0,440 \quad$ Akuntansi Pertanggungjawaban artinya konstanta sebesar 20,097 dengan arah hubungannya positif menunjukkan bahwa apabila variabel akuntansi pertanggungjawaban dianggap konstan maka kinerja manajerial sudah terbentuk sebesar 20,097, Koefisien regresi akuntansi pertanggungjawaban terhadap kinerja manajerial adalah positif sebesar 0,440. Apabila akuntansi pertanggungjawaban ditingkatkan $100 \%$ maka akan meningkatkan kinerja manajerial sebesar $44 \%$.

Pengujian hipotesis dengan uji $t$ diperoleh bahwa akuntansi pertanggungjawaban berpengaruh signifikan terhadap kinerja manajerial pada Perusahaan Daerah Air Minum (PDAM) Tirtauli Pematangsiantar. Koefesien korelasi sebesar 0,614, yang artinya terdapat hubungan yang kuat antara akuntansi pertanggungjawaban dengan kinerja manajerial pada Perusahaan Daerah Air Minum (PDAM) Tirtauli Pematangsiantar. Koefesien determinasi menunjukkan angka 0,366 atau 36,6\% yang berarti bahwa tinggi rendahnya kinerja manajerial dapat dijelaskan oleh akuntansi pertanggungjawaban. Sedangkan sisanya $63,4 \%$ dijelaskan oleh faktor lainnya yang tidak dijelaskan dalam penelitian ini.

Hal ini menunjukkan bahwa jika semakin tinggi akuntansi pertanggungjawaban maka semakin efektif kinerja manajerial. Pada Perusahaan Daerah Air Minum (PDAM) Tirtauli Pematangsiantar belum optimal pada bukti pelaporan untuk kegiatan yang dilakukan serta belum terdapatnya pemisahaan biaya yang terkendali dengan yang tidak terkendali. Karena tidak adanya pemisahan biaya tersebut membuat jumlah biaya PDAM melebihi dari yang dianggarkan.

Perusahaan Daerah Air Minum (PDAM) Tirtauli Pematangsiantar sebaiknya melakukan pemisahaan biaya dan membuat akun biaya untuk biata tidak terduga 
(kejadian alam), agar realisasi anggaran untuk biaya tidak melebihi yang dianggarkan setiap tahunnya.Penerapan akuntansi pertanggungjawaban yang baik akan mampu menciptakan kinerja organisasi yang dilakukan oleh pusat pertanggungjawaban, yang digunakan untuk setiap bagian dalam organisasi yang memiliki manajer yang mengendalikan dan bertanggung jawab atas biaya, laba, dan investasi. Semangat kerja meningkat karena mereka yakin bahwa mereka bekerja untuk tujuan bersama (Garrison, et all, 2013).

Penelitian ini sejalan dengan penelitian yang dilakukan oleh Kadek Novita Cahyani, Dan I Gst Ayu Eka Dama Yanthi (2019), Fadil Hanafiah dan Leny Suzan (2016), Mega Satrio Lukito, dan Endang Dwi Retani (2015) Linda Dyah Kinansih, dan Mimin Nur Aisyah (2013), dan Se Tin dan Taufik Hidayat (2012), bahwa akuntansi pertanggungjawaban berpengaruh terhadap kinerja manajerial. Berdasarkan penelitian di atas, maka penulis dapat menyimpulkan bahwa dengan semakin baik penerapan akuntansi pertanggungjawaban akan semakin meningkatkan kinerja manajerial, demikian juga sebaliknya semakin menurunnya penerapan akuntansi pertanggungjawaban maka kinerja manajerial akan menurun.

\section{SIMPULAN DAN SARAN}

Akuntansi pertanggungjawaban berpengaruh positif terhadap kinerja manajerial Pada Perusahaan Daerah Air Minum (PDAM) Tirtauli Pematangsiantar. Uji $\mathrm{t}$ diperoleh bahwa akuntansi pertanggungjawaban berpengaruh signifikan terhadap kinerja manajerial pada Perusahaan Daerah Air Minum (PDAM) Tirtauli Pematangsiantar. Uji $t$ diperoleh bahwa akuntansi pertanggungjawaban berpengaruh signifikan terhadap kinerja manajerial pada
Perusahaan Daerah Air Minum (PDAM) Tirtauli Pematangsiantar. Melalui penelitian ini, menyarankan agar semakin baik dalam hal penerapan akuntansi pertanggungjawaban yang akan semakin meningkatkan kinerja manajerial, demikian juga sebaliknya semakin menurunnya penerapan akuntansi pertanggungjawaban maka kinerja manajerial akan menurun.

\section{DAFTAR PUSTAKA}

Cahyani, K. N., \& Damayanthi, I. G. A. E. (2019). E-Jurnal Akuntansi Pengaruh Penerapan Akuntansi Pertanggungjawaban , Kompetensi dan Komitmen Organisasi Terhadap Kinerja Manajerial Fakultas Ekonomi dan Bisnis Universitas Udayana ( Unud ), Bali , Indonesia PENDAHULUAN Perusahaan tentunya memiliki tujuan. E-Jurnal Akuntansi, 28(1), 270-295.

Hansen dan Mowen. (2013). Akuntansi Manajerial. Jakarta: Salemba Empat.

Garrison, Ray H, Norren, Brewer. 2013. Managerial Accounting, $14^{\text {th }}$ Edition, dialihbahasakan oleh Kartika Dewi, "Akuntansi Manajerial. Buku 1". 2. Jakarta: Salemba Empat

Kinasih, L. D., \& Aisyah, M. N. (2013). Pengaruh Penerapan Akuntansi Pertanggungjawaban Terhadap Kinerja Manajerial Dengan Motivasi Sebagai Variabel Intervening (Survei Pada Pt Taman Wisata Candi Borobudur, Prambanan,Dan Ratu Boko). Nominal, Barometer Riset Akuntansi Dan Manajemen, 2(2), 97116.

https://doi.org/10.21831/nominal.v2i2. 1666

Lubis, F. H., \& Suzan, L. (2016). PENGARUH PENERAPAN AKUNTANSI PERTANGGUNGJAWABAN 
TERHADAP

KINERJA

MANAJERIAL ( Studi Kasus pada PT

. Perkebunan Sumatera Utara ). ISSN : 2355-9357 E-Proceeding of Management, 3(2), 1523-1529.

Lukito, M. S. (2015). Pengaruh Partisipasi Anggaran dan Akuntansi Pertanggungjawaban terhadap Kinerja Manajerial. Jurnal Ilmu \& Riset Akuntansi, 4(12), 1-17.

Mahoney, T. A., T. H. Jerdee and S. J. Carroll. 1963. Development of Managerial Performance: A Research Approach, Cincinnati: South Western Publ.Co

Mulyadi. 2008. Sistem Akuntansi, Edisi Tiga. Jakarta: Salemba Empat

Rahmawati, Y., Budiwibowo, S., \& Murwani, J. (2017). Pengaruh Partisipasi Anggaran dan Akuntansi Pertanggungjawaban Terhadap Kinerja Manajerial PT. KAI PERSERO DAOP VII MADIUN. Forum Ilmiah Pendidikan Akuntansi Universitas PGRI Madiun, 5 No. 1(2337-9723), 347-363.

Sari, D. (2013). Pengaruh Partisipasi Anggaran dan Akuntansi Pertanggungjawaban Terhadap Kinerja Manajerial PT. POS Indonesia. E-Jurnal Binar Akuntansi, 2(1), 1-9. https://doi.org/10.1515/bchm2.1967.3 48.1.308

Sembiring, L. D., Sudirman, A., \& Silitonga, H. P. (2020). Dampak Kejelasan Sasaran Anggaran dan Komitmen Organisasi dalam Meningkatkan Kinerja Aparat Pemerintah Daerah Kota Pematangsiantar. 3(2), 436-445

Silalahi, M. et al. (2020). Manajemen Pemerintahan. Gorontalo: Ideas
Publishing

Silitonga, H. P., \& Astuty, W. (2018). Pengaruh Partisipasi Anggaran dan Akuntansi Pertanggungjawaban Terhadap Kinerja Manajerial dengan Pengendalian Diri ( Locus Of Control ) Sebagai Variabel Moderasi ( Studi Kasus Pada Organisasi Perangkat Daerah ( OPD ) Kota Pematangsiantar ). АРPPTMA, 1-9.

Suleman, A. R. et al. (2020). BUMDES: Menuju Optimalisasi Ekonomi Desa. Medan: Yayasan Kita Menulis

Tin, S., \& Hidayat, T. (2012). Analisis Pengaruh Penerapan Akuntansi Pertanggungjawaban Terhadap Kinerja Manajer Pusat Laba Di Warung Paskal Bandung. Jurnal Akuntansi Maranatha, 4(2), 187-199. https://doi.org/10.28932/jam.v4i2.350 